\title{
MOTIVATION FOR LEARNING AND ENGLISH CONVERSATION THROUGH FILM MEDIA WITH DUBBED AND SUBTITLED METHODS
}

\author{
Musdalifah ${ }^{*}$ \\ Satriani ${ }^{2}$ \\ 1,2 Institut Agama Islam As'adiyah Sengkang, Sengkang, Indonesia \\ miss.ifah28@gmail.com ${ }^{1^{*}}$ \\ satrianiani200894@gmail.com $^{2)}$
}

\author{
Keywords: \\ [Motivation, Film \\ Media, Dubbing, \\ Subtitling]
}

\begin{abstract}
The key to inspiring pupils to study and communicate in English is to provide engaging educational media and effective learning methods. One of the most intriguing is the use of cinema media as a teaching medium. The film tells an intriguing story in the style of graphic animation and includes auditory sound to captivate students who want to learn English. Furthermore, effective learning strategies can help students understand what they are being taught. One of the learning approaches that can be utilized to urge students to communicate in English is to use dubbing and subtitling. Dubbing is a technique for imitating the voices of actors in films who perform certain parts. Because they appear to be acting out film dialogue scenes depicted by actors, this helps increase pupils' interest in conversing in English. The method of showing film dialogue at the bottom of the screen is known as subtitles. In other words, as a tool for students to absorb the material supplied, teaching media and learning methods are linked and mutually beneficial. Students can be helped to engage in language learning while also being motivated to speak in English using effective and efficient media and approaches.
\end{abstract}

Published by:

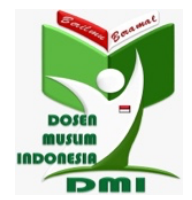

Copyright (C) 2021 The Author(s)

This article is licensed under CC BY 4.0 License (cc) $\mathrm{Br}$

https://dmi-journals.org/jai 


\section{Introduction}

One of the major influences on the teaching and learning process is motivation (Mahadi \& Jafari, 2012; Abou El-Seoud et al., 2014). The involvement and responsiveness of pupils to the content being taught demonstrates the impact of motivation on learning (Guthrie \& Davis, 2003; Cavanagh, 2011). The stronger the pupils' involvement and responsiveness to learning, the higher their learning achievement. This is also true when learning English, particularly conversational English.

Many students, in fact, are unmotivated to participate in and reply to English conversation activities (Allen, 2010; DeWaelsche 2015). This is due to the teacher's lack of involvement in pushing students to participate in this English conversation practice. Students, for example, are not given fascinating teaching materials while also not receiving adequate and supporting learning methods, resulting in their lack of enthusiasm in studying English, especially English conversation content. In fact, one of the key aims of studying English in the face of scientific breakthroughs in the current era of globalization is the ability to speak English (Kirkgöz, 2009; Shih, 2010; Pun, 2013; Kramsch, 2014).

One of the most challenging abilities for students to master is English conversation skills (Nazarah, 2011). When it comes to communicating in English, many pupils have some challenges. despite the fact that they have spent years studying English Students may believe they are unable to communicate in English because they lack English vocabulary, making it difficult to explain ideas or concepts when talking in English (Goh, 2000; Malik et al., 2021). They are also apprehensive about their capacity to pronounce English language and lack confidence in their abilities to do so. As a result, we require some practical and successful strategies to encourage kids to study and communicate in English.

Providing engaging educational media and effective learning approaches is one way to encourage students to learn and communicate in English (Amine et al., 2012; Kheryadi, 2018). Using cinematic media as a teaching tool is one of the more fascinating options (Munir, 2016). The film is a visual medium that can entice children to learn English by using animation and graphics. The picture also has an intriguing plot and a variety of inventive details. In other words, film media can assist students who are interested in studying English and eager to participate in it.

Furthermore, effective and efficient learning strategies might aid pupils in comprehending the material presented. Using dubbing and subtitling methods is one of the learning approaches that may be used to push pupils to communicate in English (Danan, 2010; Almeida \& Costa, 2014; Lertola \& Mariotti, 2017). Dubbing is a technique for emulating the voices of actors in movies who perform certain parts (Chaume, 2020). Students may get more interested in speaking in English as a result of this. While subtitling is a way of translating a film's speech and displaying it at the bottom of the screen, it can assist pupils in learning English film conversation vocabulary (Diaz-Cintas, 2013; Simanjuntak \& Basari, 2016). To put it another way, instructional media and learning methods are two critical components that cannot be separated and complement one another as a means for students to comprehend the material presented. Students can be motivated to learn English and communicate in English by using effective and efficient media and approaches. 


\section{Implementation Method}

The service is carried out by holding English learning and conversation activities through dubbing and subtitling methods. The students being trained are from class IX at MTs Binaan As'adiyah Sengkang. During the activity, the presenters will use teaching media in the form of films and dubbing and subtitling methods to motivate students in English conversation and, at the same time, train students' English conversation skills by applying dubbing and subtitling methods that have been taught. It is hoped that in the future, English conversation skills will be further improved and you will be able to apply dubbing and subtitling methods in English conversation activities.

\section{Preparation for Community Service Activities}

Before the activity is carried out, the following preparations are made:

1. Conduct a review of the literature on English conversation teaching and learning materials.

2. Prepare materials and supporting tools in the form of films as a medium for teaching English conversation, as well as dubbing and subtitling as a method of learning English conversation.

3. Conduct a trial of the design of the material to be delivered.

4. Determine the implementation time and duration of service activities with the implementing team.

5. Determine and prepare materials to be delivered as part of community service activities.

\section{Implementation of Service Activities}

The service activity took place on Saturday, May 20, 2018, from 08.00 WIB to 11.00 WIB and was attended by 40 participants from class IX students of MTs Binaan As'adiyah Sengkang. The service activity took place in the classroom of MTs fostered by As'adiyah Sengkang. The service activity begins with the delivery of the main material for activities related to teaching media and English conversation learning methods. Then, the presenters used film media in teaching English conversation as well as explaining the dubbing and subtitling methods that can be applied in English conversation. English conversation activities are directly practiced by students. The speaker directs students to practice English conversation based on the films they see by applying the dubbing and subtitling methods. At the end of the activity, the speaker gave a game about English conversation by determining some interesting topics, and students would practice one of the topics they chose.

\section{Target Audience}

The target audience chosen were students of MTs Binaan As'adiyah Sengkang. Some of the students selected are students who are currently in class IX.

\section{Relevance for Students}

This service activity has relevance to the needs of students at school. Interesting teaching media and English conversation learning methods will motivate students to 
engage in English conversation activities. The students had a new experience using film media to learn English conversation. And at the same time, they can also practice English conversation activities in daily life by applying the dubbing and subtitling methods that have been taught.

\section{Results and Discussion}

\section{Results}

Based on interviews, questions and answers, and direct observations made during the activity, this community service activity gave the following results:

1. Increased knowledge and understanding of grade IX students at MTs Binaan As'adiyah Sengkang. in using film media by applying dubbing and subtitling methods in learning and speaking English.

2. 2. Increasing the skills of class IX students at MTs Binaan As'adiyah Sengkang in using film media by applying dubbing and subtitling methods to learning and speaking English.

\section{Supporting factors and inhibiting factors}

Several factors that support the implementation of this community service activity are School IX at MTs Binaan As'adiyah Sengkang's support for the implementation of the speaker's activities, as well as the amount of interest and enthusiasm of the participants during the activity so that the activity runs smoothly and effectively. While the inhibiting factor is the limited training time.

\section{Understanding of Materials Regarding Dubbing and Subtitling Methods}

Dubbing is a method of imitating the voices of actors who play specific roles in films. The dubbing method is used to practice English conversation by imitating the voices of actors in films, with the goal of increasing knowledge of English vocabulary pronunciation (pronunciation) and improving skills in how to pronounce English vocabulary correctly.In other words, the dubbing method can make students interested in being involved and able to pronounce English vocabulary correctly while communicating using English because they seem to be involved in imitating and acting out dialogue conversations or scenes played by actors in the film.

Subtitling is a method of transcribing the film's dialogue in English, which is displayed at the bottom of the screen. There are two subtitling methods used in this activity. First, subtitles with Indonesian transcription. This subtitling method is used to help students understand the film because the subtitles are presented in the form of an Indonesian transcription, thus helping students know the meaning of the vocabulary in the film dialogue and making it easier to understand the meaning of the English conversational vocabulary in the film dialogue. Second, subtitling with English transcription. This English subtitling method is used to help students use appropriate English vocabulary in practicing and practicing English film dialogue conversations. In other words, through this subtitling method, students can easily use the transcription of English dialogue film dialogues that are displayed at the bottom of the screen, which will later be trained and practiced in the real world or in daily activities. 


\section{Procedure for the Implementation of the Dubbing and Subtitling Method}

Several stages or procedures for implementing the dubbing and subtitling method as a guide to train students' English conversation skills in this community service activity are as follows:

1) Screening stages for films with Indonesian subtitles (Indonesian-subtitled version).

At this stage, students are directed to watch a film entitled "Finding Nemo" and receive the following instructions:

a. Students listen to and watch the film Finding Nemo carefully and pay attention to the Indonesian subtitled version of the transcription. The purpose of this Indonesian-language transcription method is to help students understand the content and storyline of the film because it is presented using an Indonesianlanguage transcription, which is displayed at the bottom of the screen. In other words, students understand the film's story by looking at the Indonesian subtitles at the bottom of the film (text media).

b. Students answered several questions related to the film Finding Nemo (5 W + $1 \mathrm{H}$ ) as follows: When and where did the movie happen?, Who are the actors? Who is involved in the movie?, What does the movie talk about?, Why is the movie's ending sad or happy?, When does the movie end? (Are you sad or happy)?

c. Students retell the film's story by making their own notes using their own ideas or ideas and words.

2) Stages of showing films with English subtitles (English subtitled version)

At this stage, students are directed to watch and listen to the film titled "Finding Nemo" carefully by applying the subtitle method and receiving the following instructions:

a. Students listen to and watch the film Finding Nemo carefully using the subtitle method.

b. Students are taught the subtitling method in the following ways:

- Pay attention to the English subtitles (transcriptions) displayed at the bottom of the film (English subtitled version).

- Make a note of the vocabulary used by the actor in the film (noting the unknown vocabulary).

- Finding the meaning of the vocabulary that has been obtained by looking at the dictionary and is also assisted by providing some vocabulary and meaning in the film's dialogue. Matching the use of vocabulary in film dialogues by discussing the use of vocabulary or expressions in the subtitles of film dialogues through a random guessing game of film dialogue conversations (games).

c. Students are instructed to use subtitled films to practice speaking English. At this stage, students are instructed to memorize the vocabulary of subtitled dialogue in English films by applying the technique of remembering. Specifically, students are directed to recall the vocabulary in the film and 
imitate the subtitles. Moreover, students are directed to practice speaking English skills by imitating vocabulary. the word is shown at the bottom of the film.

Some of the instructions given and directed to students aim to help students remember and understand vocabulary in film dialogues as well as train students' speaking skills by imitating what is transcribed in the film dialogues so that students are trained independently to practice dialogue in films.

3) Offering Movies with dubbing method

At this stage, students are directed to watch and listen to the film titled "Finding Nemo" carefully by applying the dubbing method and obtaining the following instructions:

a. Students listen to and watch the film Finding Nemo carefully using the dubbing method.

b. Students are taught the dubbing method in the following ways:

- Pay close attention and listen to the pronunciation of vocabulary in film dialogue (pronunciation) and how to pronounce vocabulary in film dialogue (how to pronounce the word). At this stage, students are instructed to learn the vocabulary of English film dialogues by applying imitating techniques. Specifically, students are directed to practice speaking English skills by imitating the vocabulary spoken by the actors in the film.

- Presenting and explaining some important vocabulary along with their definitions or meanings to increase knowledge of the vocabulary used in the film's dialogues.

- Presenting and explaining knowledge of how to pronounce some important vocabulary in films

- Replay some shows on how to pronounce vocabulary in film dialogues and train students to pronounce vocabulary in film dialogues. Students are directed to practice speaking English skills by playing back original films without subtitles. In this case, students practice film dialogues based on scenes with dubbing techniques, namely by imitating the conversational dialogues said by the actors in the film. At this stage, students act out film dialogue scenes as if they were actors, imitating the voices of the actors.

Dubbing in English (Original). Through English dubbing, students can practice their English speaking skills because students are trained and directed to practice conversations in film dialogues by imitating the voices performed by actors using the film's original language or in English.

Dubbing in Indonesian. Through dubbing in Indonesian, it can help students understand the story of the film as well as increase vocabulary and its meanings, so as to help students understand the meaning of vocabulary as well as determine the right vocabulary to fill in the voices in the film. 


\section{Conclusion}

From this community service activity, it can be concluded that:

a. Knowledge and understanding of class XI students of MTs Binas As'adiyah Sengkang about the use of films in learning English conversation by applying dubbing and subtitling methods.

b. New experiences and skills of Class XI students of MTs fostered by As'adiyah Sengkang regarding the use of films in learning English conversation by applying the dubbing and subtitling methods

Given the magnitude of the benefits of this community service activity, Next need:

a. Providing the same training to a larger target audience on a variety of Englishlanguage materials.

b. Train English teachers on effective and efficient English teaching media and learning methods.

\section{References}

Abou El-Seoud, M. S., Taj-Eddin, I. A., Seddiek, N., El-Khouly, M. M., \& Nosseir, A. (2014). E-learning and students' motivation: A research study on the effect of e-learning on higher education. International journal of emerging technologies in learning (iJET), 9(4), 20-26.

Allen, H. W. (2010). Language-learning motivation during short-term study abroad: An activity theory perspective. Foreign Language Annals, 43(1), 27-49.

Almeida, P. A., \& Costa, P. D. (2014). Foreign language acquisition: the role of subtitling. Procedia-Social and Behavioral Sciences, 141, 1234-1238.

Amine, B. M., Benachaiba, C., \& Guemide, B. (2012). Using Multimedia to Motivate Students in EFL Classrooms: A Case Study of English Master's Students at Jijel University, Algeria. Malaysian Journal of Distance Education, 14(2).

Cavanagh, M. (2011). Students' experiences of active engagement through cooperative learning activities in lectures. Active learning in higher education, 12(1), 23-33.

Chaume, F. (2020). Audiovisual translation: dubbing. Routledge.

Danan, M. (2010). Dubbing projects for the language learner: a framework for integrating audiovisual translation into task-based instruction. Computer assisted language learning, 23(5), 441-456.

DeWaelsche, S. A. (2015). Critical thinking, questioning and student engagement in Korean university English courses. Linguistics and Education, 32, 131-147.

Díaz-Cintas, J. (2013). Subtitling: Theory, practice and research. In The Routledge handbook of translation studies (pp. 291-305). Routledge.

Goh, C. C. (2000). A cognitive perspective on language learners' listening comprehension problems. System, 28(1), 55-75. 
Guthrie, J. T., \& Davis, M. H. (2003). Motivating struggling readers in middle school through an engagement model of classroom practice. Reading \& writing quarterly, 19(1), 59-85.

Kheryadi, K. (2018). The implementation of "WHATSAPP" as a media of English language teaching. Loquen: English Studies Journal, 10(2), 1-14.

Kirkgöz, Y. (2009). Globalization and English language policy in Turkey. Educational policy, 23(5), 663-684.

Kramsch, C. (2014). Teaching foreign languages in an era of globalization: Introduction. The modern language journal, 98(1), 296-311.

Lertola, J., \& Mariotti, C. (2017). Reverse dubbing and subtitling: Raising Pragmatic awareness in Italian English as a second language (ESL) Learners. The Journal of Specialised Translation, 28, 103-121.

Mahadi, T. S. T., \& Jafari, S. M. (2012). Motivation, its types, and its impacts in language learning. International Journal of Business and Social Science, 3(24).

Malik, H., Humaira, M. A., Komari, A. N., Fathurrochman, I., \& Jayanto, I. (2021). Identification of barriers and challenges to teaching English at an early age in Indonesia: an international publication analysis study. Linguistics and Culture Review, 5(1), 217-229.

Munir, F. (2016). The effectiveness of teaching vocabulary by using cartoon film toward vocabulary mastery of EFL students. Journal of English Language Teaching and Linguistics, 1(1), 13-37.

Nazara, S. (2011). Students' perception on EFL speaking skill development. JET (Journal of English Teaching), 1(1), 28-43.

Pun, M. (2013). The use of multimedia technology in English language teaching: A global perspective. Crossing the border: International journal of interdisciplinary studies, 1(1), 29-38.

Shih, R. C. (2010). Blended learning using video-based blogs: Public speaking for English as a second language students.Australasian Journal of Educational Technology, 26(6).

Simanjuntak, N. V. N., \& Basari, A. (2016). Subtitling strategies in Real Steel movie. LITE: Jurnal Bahasa, Sastra, dan Budaya, 12(1). 